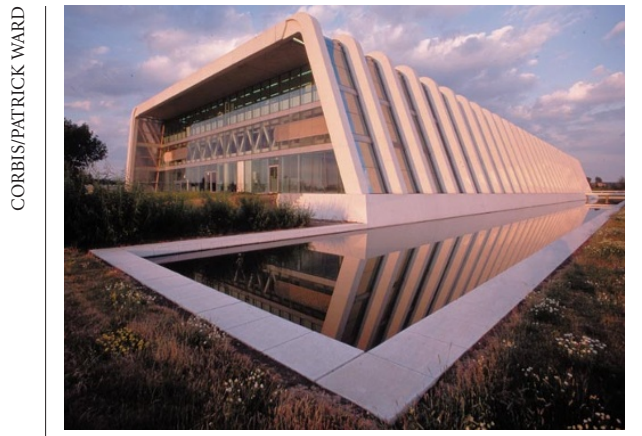

Prime location: the Napp Building, one of the research facilities at Cambridge Science Park.

tried to ease the pressure on Cambridge, and to reduce the regional economic disparity, by encouraging high-technology businesses to move to poorer rural areas. These would be linked by new roads to major inter-city roads, enabling staff to commute.

The new Labour government has taken a different approach. It cut the roads programme last year. And the SCEALA authorities, which have changed from being predominantly under Conservative control, to Labour, have decided to concentrate on urban - rather than rural - regeneration. In addition, a government committee chaired by architect Lord Richard Rogers said last week that new housing should be built on disused 'brownfield' manufacturing sites in urban areas and not on 'greenfield' rural sites.

Under SCEALA's proposed planning restrictions, new businesses would be encouraged to locate in or near towns and cities other than Cambridge. The strategy also aims to encourage greater use of public transport for travel to work.

But Bill Wicksteed of Segal Quince Wicksteed says that preventing the growth of clusters of high-technology businesses will ultimately disadvantage local communities as well as the high-technology industry itself.

"Growth should not be grudgingly accepted, but embraced and shaped," says Wicksteed. "If [local authorities] work from an assumption that growth must be resisted, they will fail. They will get growth, but they will be unable to control it."

The Wicksteed report believes that it is inappropriate for SCEALA to try to integrate its technology management policies with the aim of urban regeneration. And it doubts whether technology companies will want to move to areas where they may not be able to find enough qualified staff.

The controversy will intensify the government's difficulties over a planning application from the Wellcome Trust for a genomics research complex on the outskirts of Cambridge, which the local authority opposes. Prospects for the complex will not have been helped by the recent resignation of industry secretary Peter Mandelson, the architect of the government's decision to promote knowledge-based industry. EhsanMasood

\title{
Tough times set to continue for US biotech start-ups
}

[SAN FRANCISCO] US biotechnology companies are bracing themselves for continued financial problems in 1999 as the public markets look to industries that can provide quicker, more reliable returns on their money, according to industry analysts.

Those attending the annual Hambrecht \& Quist (H\&Q) healthcare investment conference in San Francisco last week were also told that, although investing in high-risk venture companies is likely to reach an alltime high in 1999, biotechnology is unlikely to enjoy the benefits.

Industry observers did not believe that the fall in funding would trigger a slowdown in science. "There's such innovation in biomedical research that, for every failure, there are probably ten professors writing a business plan," says Alex Zisson, pharmaceutical analyst for the investment company.

But even top university administrators acknowledge that outside interest in licensing products or funding start-up companies from bioscience research has slipped. Katherine $\mathrm{Ku}$, director of the office of technology licensing at Stanford University, says that entrepreneurial activity in the physical sciences has outstripped biotechnology for several years.

About 20 biotechnology companies, including some long-established ones, slashed operations or closed their doors entirely last year due to the cash crisis. Casualties included Alpha One, Biocircuits, Cellex, Cellpro, ChemTrack and ImmuLogic, and more failures are predicted this year.

"Too much capital is needed to bail everybody out," says Dennis Purcell, managing director and head of life sciences banking for H\&Q. He predicts that smaller companies will find it hard to raise the money they need.

According to Purcell, about 95 biotechnology companies have less than one year of cash available to fund operations. The industry raised only $\$ 951$ million in public shares last year - a 60 per cent drop from the $\$ 2.28$ billion collected in 1997. Initial money raised in shares was $\$ 417$ million in 12 companies launched on the stock market, 44 per cent down from the $\$ 750$ million collected the year before in 22 flotations.

Kurt Von Emster, portfolio manager for the Franklin Biotechnology Fund, attributes much of the crisis to the high level of enthusiasm in 1991 and 1992, which fuelled a boom of marginal companies and products. But poor market performance for six years running and the largest ever number of projects in which drugs failed to fulfil their promise have created a desperate need for capital, he adds.

Von Emster estimates that about a quar- ter of public biotech companies need to raise money, while another 100 are still waiting to go public after six years of private operations. "About $\$ 5$ to $\$ 8$ billion need to be raised over the next 16 to 18 months," he said. "That's just not going to happen."

Even though the Nasdaq biotechnology shares index climbed 40 per cent over the year, representing a sharp recovery from falls of 2 per cent in 1997 and 1 per cent in 1996, most of the gain came from the top ten companies. Almost two-thirds of publicly quoted companies in the sector lost value, and 50 are trading below their cash value, says Purcell.

But he is optimistic that investors will return, lured by the gap between low stock valuations and the value represented by product potential and real revenues.

Venture capitalists at the H\&Q conference said that, while funding is more difficult to come by these days, good ideas will not go begging. They seemed most charmed by promises of steady revenue from young companies that could sell subscriptions or service contracts for platform technologies such as genomics or drug-target validation.

Zisson points out that, although enthusiasm for technology transfer in the academic world remains high, in today's climate a great technological product is not enough: scientists must come up with a smart business plan as well.

Lita Nelson, director of technology licensing at the Massachusetts Institute of Technology, says that, as leading venture companies have become consolidated, this has left a gap at the level of creating companies. The pioneer funds have become so successful that they cannot afford to make smaller investments or put the time into helping small companies get started.

While a few new venture companies have moved in, start-ups have lost the benefit of the older, established venture capitalists' experience, say Nelson and others. These young companies will probably have a hard time surviving entrepreneurial speed bumps, such as raising more capital when needed. "These companies won't be as successful when they run into trouble," says Nelson.

Jeff Casdin, chief executive of Casdin Capital Partners, is optimistic that there will eventually be a broad recovery in the value of biotechnology shares. He predicts that the scientific potential will become irresistible to investors.

"If the stuff is good, interesting, kicking, I don't think it's hard to get attention,' says Jan zur Hausen, an associate with MPM Asset Management of Cambridge, Massachusetts.

SallyLehrman 